\title{
Applying mass spectrometric methods to study androgen biosynthesis and metabolism in prostate cancer
}

\author{
Matias Knuuttila1, Esa Hämäläinen² and Matti Poutanen ${ }^{1,3}$ \\ IInstitute of Biomedicine, Research Centre for Integrative Physiology and Pharmacology, and Turku Center for Disease Modeling, Institute of Biomedicine, \\ University of Turku, Turku, Finland \\ 2Department of Clinical Chemistry and HUSLAB, Helsinki University and Helsinki University Hospital, HUSLAB, Helsinki, Finland \\ 3Institute of Medicine, Sahlgrenska Academy, University of Gothenburg, Gothenburg, Sweden
}

Correspondence should be addressed to M Poutanen: matti.poutanen@utu.fi

\begin{abstract}
Recent development of gas chromatography and liquid chromatography-tandem mass spectrometry (GC-MS/MS, LC-MS/MS) has provided novel tools to define sex steroid concentrations. These new methods overcome several of the problems associated with immunoassays for sex steroids. With the novel MS-based applications we are now able to measure small concentrations of the steroid hormones reliably and with high accuracy in both body fluids and tissue homogenates. The sensitivity of the tandem mass spectrometry assays allows us also for the first time to reliably measure picomolar or even femtomolar concentrations of estrogens and androgens. Furthermore, due to a high sensitivity and specificity of MS technology, we are also able to measure low concentrations of steroid hormones of interest in the presence of pharmacological concentration of other steroids and structurally closely related compounds. Both of these features are essential for multiple preclinical models for prostate cancer. The MS assays are also valuable for the simultaneous measurement of multiple steroids and their metabolites in small sample volumes in serum and tissue biopsies of prostate cancer patients before and after drug interventions. As a result, novel information about steroid hormone synthesis and metabolic pathways in prostate cancer has been obtained. In our recent studies, we have extensively applied a GC-MS/MS method to study androgen biosynthesis and metabolism in VCaP prostate cancer xenografts in mice. In the present review, we shortly summarize some of the benefits of the GC-MS/MS and novel LC-MS/ MS assays, and provide examples of their use in defining novel mechanisms of androgen action in prostate cancer.
\end{abstract}

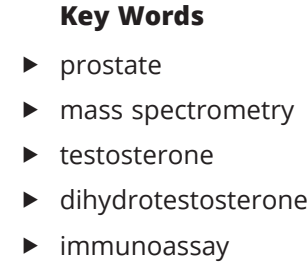

Journal of Molecular Endocrinology (2019) 62, R255-R267 


\section{Development of highly sensitive mass spectrometric assays for analyzing androgens in body fluids and tissues}

To provide solid evidence for the role of local steroid metabolism as a key regulatory step in sex steroid biology we and several other research groups have actively developed liquid chromatography-tandem mass spectrometric (LCMS/MS) and gas chromatography (GC)-MS/MS methods to analyze multiple unconjugated and/or conjugated steroid hormones simultaneously in body fluids and tissue biopsies. Indeed, the value of MS assays in obtaining novel data in both clinical specimens and preclinical models is well demonstrated (e.g. Vandenput et al. 2007, Harwood \& Handelsman 2009, Arlt et al. 2011, Keski-Rahkonen et al. 2011, Keski-Rahkonen et al. 2013, Tamae et al. 2013, Ke et al. 2015, Nilsson et al. 2015, Boggs et al. 2016, Snaterse et al. 2016, Zang et al. 2017, Häkkinen et al. 2018). The discussion and debate for the benefits and drawbacks of steroid hormone analysis using either MS or immunoassay methodology has been active, and well-summarized in recent reviews (Taylor et al. 2015, Cross \& Hornshaw 2016, Handelsman 2017, Wudy et al. 2018). However, while validated immunoassays may be adequate for the screening of serum testosterone (T) concentrations in the normal physiological range of men (Taylor et al. 2015), problems with sensitivity, specificity and reproducibility of the direct immunoassays emerge for most androgens and estrogens when those are applied to low levels, such as in postmenopausal women, children and men with suppressed gonadal function. While the performance of the immunoassays may be improved by using liquid or solid-phase extraction and chromatographic separation, or other preanalytical sample handling procedures before the immunoassay, the use of these procedures are often abolished, because the benefits of automatization and high throughput of these assays are then lost. Furthermore, it is very difficult and laborious to produce specific, high-affinity antibodies against all steroids and their metabolites, but almost all of the steroids can be ionized, and they give reasonable fragmentation in MS, so they can be analyzed and quantitated with MS/MS assays.

Sensitivity of MS/MS assays are superior to immunoassays (picomolar to femtomolar levels of steroids vs nanomolar to picomolar levels with immunoassays). Most commercial direct immunoassay of steroids (luminometric or immunofluorometric methods) do not measure steroid levels reproducibly below $20 \mathrm{pmol} / \mathrm{L}$, and moreover, the accuracy of the immunoassays compared to reference methods is low at these low levels. For example, the reproducibility of direct estradiol assays below the concentration of $100 \mathrm{pmol} / \mathrm{L}$ is often unacceptable (more that $20 \% \mathrm{CV}$ ). Furthermore, reproducibility of LC-MS/MS is better than in most steroid immunoassays in a large concentration range. Moreover, stable isotope-labeled internal standards with physicochemical properties similar to the analytes are used to increase the precision and accuracy of the MS/MS methods, leading to improved intra-injection reproducibility and reduction of matrix and ionization effects (Bergeron et al. 2009, Bronsema et al. 2012).

For clinical purposes, MS assays and immunoassays are currently at very different phases of their maturity. While immunoassays have been performed for decades in routine laboratories, the technical and methodological development of MS/MS methods has been rapid during the recent 10 years. The high initial equipment cost and the costs of maintenance are often considered to be significant obstacles to MS technique use in research laboratories. Compared to immunoassay, MS methodology also needs special technical expertise, which can be difficult to obtain, if the laboratory has no previous experience of chromatographic techniques or MS technology. However, the development of user-friendly software and easy accessible structures of MS equipment have made the operation and their routine maintenance rather easy. Thus, in many laboratories LC-MS/MS and GC-MS/MS equipment are run routinely alone by educated laboratory technicians after the validation of the method by chemists. Moreover, tested and pre-validated methods for steroid analyses are nowadays available for certain LC-MS/ MS instruments by the instrument manufacturers. These are available for both single analytes (testosterone (TS), estrone, estradiol) and steroid profiles.

The high-throughput and extensively automatized procedures reducing the costs have been the benefits of the immunoassays applied in clinical laboratories and big study cohorts. However, the development of preanalytical pipetting automation for solvent transfer and liquid-liquid or solid-phase extraction, and the use of multiplexing techniques with synchronized injections of two to four HPLC systems incorporated to single MS unit, has become an effective tool for improving throughput of MS methods (Bayliss et al. 2000, Jannetto \& Fitzgerald 2016). The multiplexing technique utilizes the fact that in most of the MS assays the analyte or analytes of interest are typically separated by a few seconds so that the chromatographic run is completed within some minutes. By combining profiling method and multiplexing technique makes it possible to further increase the capacity 
of the MS method, and significantly reduce the cost of a single sample to a level which is competitive compared with any steroid immunoassay. Thus, it seems that the use of immunoassays for steroid hormone analysis is rapidly reducing, and in the future will be limited mainly to some automated routine methods and screening purposes in clinical laboratories.

It is evident that MS assays have significantly improved the specificity of steroid measurements. This is largely due to the fact that MS methodology gives direct structural data of the analyte which cannot be obtained with immunological techniques. Thus, for the steroid research, the MS/MS assays are the methods of choice already today for measuring the serum and tissue concentrations of sex steroids in many preclinical models. Measuring steroids in mice and rats is even more challenging than in humans, due to their lower concentrations in rodents (Nilsson et al. 2015). One of the reasons for the low circulating sex steroid levels in rodents is that, in contrast to human, they do not present with sex steroid hormone-binding globulin (SHBG) in the circulation. In primates, SHBG binds to circulating sex steroids and limits the amount of free form of the steroids available for target tissues. It was recently demonstrated that expression of SHBG in transgenic mice, indeed, increases the total serum level of TS (Laurent et al. 2016), providing a convincing proof for the free hormone theory as one of the feedback mechanism for the regulation of sex steroid concentrations in circulation. While validated immunoassays for TS measurement (Huhtaniemi et al. 1985) in male mice have provided quite an acceptable performance, none of the direct immunoassays has been sensitive or reliable enough, for example to measure normal physiological (picomolar) levels of estradiol in mice. Thus, one should be cautious when conclusions are drawn from studies where estradiol concentration in mice has been measured with immunoassays, and we advise that any critical study should be confirmed by highsensitivity MS/MS assays.

As addressed above, one significant problem associated with the steroid immunoassays is the crossreactivity of the antibodies with other closely related steroids. Although the cross-reactivity is not a significant obstacle in many clinical studies with high physiological concentrations of the steroid hormones, even a low crossreactivity becomes a problem in any clinical or preclinical study that involves administration of a pharmacological or supraphysiological dose (Husen et al. 2006, Savolainen et al. 2007) of a steroidal compound. Unlike immunoassays, MS techniques can be used to measure the steroids with high specificity also with big differences in the concentrations of the related steroids. In addition, the dynamic range of the physicochemical MS methods is superior compared to immunoassays.

Poor ionization properties of certain steroids have been one of the challenges in some MS methods, leading to low sensitivity of these assays. Thus, derivatization of the steroids has often been a prerequisite procedure for improving the sensitivity (Keski-Rahkonen et al. 2011, Häkkinen et al. 2018), but it also increases the complexity, reproducibility and the workload of the method. Nevertheless, the current LC-MS/MS-based assays without derivatization provide very high sensitivity with reference level specificity, also with multianalyte methods; however, neither with MS methodology is it simple to guarantee the right or accurate result of certain steroid. Especially one must be careful when analyzing steroids in lipid-rich tissues using MS methods (Liere \& Schumacher 2015). All the phases of the analysis must be carefully tested, including efficiency of the extraction of the steroids (liquid-liquid or solid-phase), solubility of steroids to organic or water-based solvents and buffers used and the efficiency in the purification and separation with chromatographic procedures. Especially, the deconjugation of steroid conjugates via solvolysis or hydrolysis during the process and the conversion of steroids to their metabolites must be carefully tested for proper quantitation of steroids using MS assays. Taking the issues above into a count, with the state-of-the-art GCand LC-MS/MS techniques, we can now measure several androgens with methods being sensitive enough to most applications both in human and preclinical studies (see, for example Harwood \& Handelsman 2009, Nilsson et al. 2015, Häkkinen et al. 2018). However, different assay conditions are often needed for the maximal sensitivity for different steroids, and the techniques used need to be selected based on the preferred sensitivity for the steroids of highest interest (Table 1, for examples).

Due to the well-acknowledged benefits in using MS/ MS-based sex steroid assays in scientific research, the editorial board of the Journal of Clinical Endocrinology and Metabolism stated that any study published in the journal from year 2015 onwards should use MS methods for the measurement of sex steroids (Handelsman \& Wartofsky 2013). This further increased the debate on the pros and cons of such a decision amongst endocrinologists. In response to this debate, The Endocrine Society Council then brought together a Sex Steroid Assays Reporting Task Force in order to recommend the future reporting of sex steroid hormone measurements in the Society's journals. 
Table 1 Mass spectrometric assays recently applied by us to measure serum and intratissue androgen levels in preclinical models and clinical specimens.

\begin{tabular}{|c|c|c|c|}
\hline & LC-MS/MSa & GC-MS/MS & LC-MS/MS \\
\hline Estrone & 1.5 & 0.5 & 0.5 \\
\hline Estradiol & 2.5 & 0.5 & 2.0 \\
\hline Testosterone & 10 & 8 & 1 \\
\hline DHT & 50 & 2.5 & - \\
\hline $3 \alpha \mathrm{Diol}$ & 200 & - & - \\
\hline 3ßDiol & 200 & - & - \\
\hline Androstenedione & - & 12 & 4 \\
\hline Progesterone & - & 74 & 4 \\
\hline DHEA & - & 400 & 100 \\
\hline $17 \alpha$-hydroxy-progesterone & - & - & 10 \\
\hline $17 \alpha$-hydroxy-pregnenolone & - & - & 10 \\
\hline
\end{tabular}

aHarwood and Handelsman (2009); ' Nilsson et al. (2015); cHäkkinen et al. (2018).

The instructions provided did not mandate a specific type of assay for steroids, likely due to the unavailability of new GC- or LC-MS/MS methods to a large group of scientists in the field. However, the recommendation stated the criteria for a valid assay for sex steroids in clinical and nonclinical studies. For example, the commercial sex steroid assays validated for human serum must be validated to verify acceptable quantitative accuracy, precision and specificity for the analytes measured when applied in nonclinical studies performed in vitro or in animals. It was also recognized that automated and direct (unextracted) immunoassays for sex steroids might present with unacceptable bias when concentrations are low, for example in samples from children, women, hypogonadal men and postmenopausal women (Wierman et al. 2014).

We expect that the new multianalyte profiling of steroids by GC-MS/MS and LC-MS/MS methods will result in a new era in steroid biology. They will bring tremendous possibilities to discover novel ligands and functions for classical sex steroids, and enable us to identify biomarker combinations for diagnostic purposes, patient stratification and the treatments of endocrine diseases.

\section{Detecting novel androgenic ligands with mass spectrometric assays}

Although TS and dihydrotestosterone (DHT) are the primary androgens activating the androgen receptor (AR), many of the precursors for these classical androgens and their metabolites are also capable of AR binding. MS/MS methods have been critical in identifying these novel steroids, and methods are now available to measure their concentrations in serum, providing also clinical value.
Furthermore, AR mutations may also reduce the ligand specificity, causing promiscuous activation of the AR with antiandrogens, estrogens, progestins and glucocorticoids (Coutinho et al. 2016).

Besides the classical adrenal androgens, androstenedione (A-dione), dehydroepiandrosterone (DHEA) and DHEA-sulfate (DHEA-S), MS assays have shown thathumanadrenalsproduce $11 \beta$-hydroxyandrostenedione (110HA-dione) from A-dione by CYP11B hydroxylase activity (Bloem et al. 2013, Swart et al. 2013). Although 11OHA-dione has no significant androgenic activity (Bélanger et al. 1993), it can be metabolized to 11-ketoandrogens, namely to 11-ketotestosterone (11KT) and 11-ketodihydrotestosterone (11KDHT) that present with androgenic properties (Storbeck et al. 2013, Pretorius et al. 2016). These 11-ketoandrogens can be formed when the necessary enzymatic machinery is present, including $5 \alpha$-reductase, $17 \beta$-HSD and $11 \beta$-HSD activities (Swart \& Storbeck 2015). Both $11 \mathrm{KT}$ and $11 \mathrm{KDHT}$ bind to the AR with potencies similar to $\mathrm{T}$ and DHT, respectively, and induce changes in androgen-regulated gene expression and enhance androgen-dependent cell proliferation (Pretorius et al. 2016). In addition to the findings indicating that 11-ketoandrogens are derived from 110 HAdione of adrenal origin, a recent study suggested that $11 \mathrm{KT}$ is extensively produced by the Leydig cells of the testes and also by the ovarian theca cells (Imamichi et al. 2016), thus, being a gonad-produced sex steroid. However, the plasma concentrations of 110HA-dione, 11KA-dione, $11 \mathrm{OHT}$ and $11 \mathrm{KT}$ measured by LC-MS/MS are significantly increased in 21-hydroxylase (CYP21A)deficient patients, supporting the hypothesis that these steroids are originating from adrenal precursors (Turcu et al. 2016). Interestingly, remarkable levels of $11 \mathrm{KT}$ and $11 \mathrm{KDHT}$ were also detected in prostate tissue and plasma of prostate cancer (PCa) patients by LC-MS/MS (du Toit et al. 2017), suggesting their potential importance in androgen-dependent tumor growth particularly in castration-resistant prostate cancer (CRPC).

The 11-ketoandrogens are not the only novel ligands that can activate the wild-type AR. For example, 11-deoxcorticosterone (DOC), a precursor of corticosterone, has been identified as a novel substrate for Steroid 5 Alpha-Reductase 1 (SRD5A1), and DOC and its $5 \alpha$-reduced metabolite $5 \alpha$-dihydrodeoxycorticosterone (5 $\alpha$-DH-DOC) was demonstrated to promote cell proliferation through AR in PCa cell lines (Uemura et al. 2010). Furthermore, LC-MS/MS measurements have confirmed that $5 \alpha$-DH-DOC is present in tumors obtained from CRPC patients. 


\section{Novel enzymes for androgen biosynthesis}

Data from recent years have provided convincing evidence indicating that the ligand concentration available for steroid receptor binding is markedly regulated by the target tissue metabolism. The $5 \alpha$-reductase activity is a classic example of this phenomenon, as conversion of $\mathrm{T}$ to DHT has been known for a long time to be essential for prostate development and prostate hyperplasia (Mendonca et al. 2017, Banerjee et al. 2018, Matsushita et al. 2018). $5 \alpha$-reductase inhibitors, finasteride and dutasteride, are commonly described drugs for the treatment of benign prostatic hyperplasia. Finasteride specifically inhibits $5 \alpha$-reductase type 1 (SRD5A1) whereas dutasteride effectively inhibits both SRD5A1 and SRD5A2 enzymes (Clark et al. 2004, Kim et al. 2018). However, $5 \alpha$-reductase inhibitors have been shown to lead to accumulation of intratumoral T (Byrns et al. 2012, Knuuttila et al. 2018b) that has reduced the use of these compounds in PCa therapy. However, $5 \alpha$-reductase inhibitors may also slow down the progression of PCa (Cha \& Shariat 2011), while their role in PCa prevention remains controversial. Based on two big randomized trials, $5 \alpha$-reductase inhibitors decrease the incidence of PCa but also increase the risk of high-grade tumors, yet the relevance of these associations are under debate (Lacy \& Kyprianou 2014).

Equally, we know that in the postmenopausal women, majority of the estrogens are produced in peripheral tissues from the androgenic precursors produced in the ovaries and adrenals (Labrie 1991). The extragonadal estradiol production is highly related to the expression of $\mathrm{P} 450$ aromatase (Cytochrome P450, family 19) in peripheral tissues (Simpson 2002). In line with these findings, P450 aromatase inhibitors have become key players in the endocrine therapy of estrogen-dependent breast cancer in postmenopausal women (Santen et al. 2009, Zahid et al. 2016). However, current data suggest that these are just a few examples of multiple similar physiological settings in which the local sex steroid synthesis and metabolism is in a key position to regulate the hormone action both in men as well as in premenopausal and postmenopausal women.

The annotation of the whole human genome has provided evidence for the presence of up to 70 enzymes in the short-chain dehydrogenase/reductase (SDR) family (Persson et al. 2008), up to 15 enzymes in aldoketo reductase (AKR) family (Penning 2015) and about 50 CYP family enzymes (Nebert et al. 2013). In all these families, there are enzymes demonstrated to be involved in the metabolism of hydrophobic small molecules of various origins, and steroid-metabolizing enzymes have been identified in all these enzyme families. Although the catalytic properties of SDR (Oppermann et al. 1997, Wu et al. 2007) and AKR (Jin \& Penning 2007, Penning \& Drury 2007) enzyme families have been studied, some of the enzymes in these families are still poorly characterized, providing a large pool of potential novel steroid-metabolizing enzymes. This hypothesis is supported by the fact that new enzymes with steroidmetabolizing activities and novel reactions for known steroid-metabolizing enzymes are constantly identified (Neunzig et al. 2015, van Rooyen et al. 2018). These novel steroid-synthesizing enzymes and new activities associated with the classical enzymes have led to the identification of nonclassical pathways for the production of active sex steroids, including androgens (Miller 2017, Mohler 2018, Schiffer et al. 2018).

\section{Androgen biosynthesis inhibitors serve as an effective approach to treat prostate cancer}

The identification of novel tissues and pathways involved in sex steroid synthesis is also the basis for the development of new therapies affecting sex steroid-dependent diseases. Abiraterone acetate is a steroid synthesis inhibitor that is currently used in clinical practice to treat patients with CRPC. Abiraterone acetate is metabolized in vivo to abiraterone that inhibits the $17 \alpha$-hydroxylase and 17,20-lyase activity of CYP17A1, resulting to a marked, up to $90 \%$, decrease of serum $\mathrm{T}$ levels in both castrated and non-castrated patients (O'Donnell et al. 2004, Attard et al. 2005, Ryan et al. 2014). Treatment with abiraterone acetate has been shown to extend the overall survival of metastatic CRPC patients who had previously received chemotherapy for 3-4 months (de Bono et al. 2011). Treating patients with metastatic CRPC with abiraterone acetate without previous chemotherapy was also shown to be effective by improving the radiographic progressionfree and overall survival (Ryan et al. 2013). Interestingly, while abiraterone acetate treatment markedly reduces adrenal androgen concentrations in the serum of patients, DHEA-S still persists in circulation, possibly serving as a precursor for intratumoral conversion to $\mathrm{T}$ and DHT in prostate tumors (Taplin et al. 2014, Tamae et al. 2015). Strikingly, a novel abiraterone metabolite ( $\Delta 4$-abiraterone) was recently identified to inhibit HSD3B1 and SRD5A enzymes, and was also shown to act as an AR antagonist, suggesting several independent mechanisms of abiraterone action with potential clinical importance (Li et al. 2015). 
Furthermore, there are other potential ways to inhibit intratumoral androgen biosynthesis. For example, inhibitors for AKR1C3 have been developed to reduce the conversion of A-dione to T in CRPC tumors (Byrns et al. 2011). However, the development of selective AKR1C3 inhibitors is challenging as the AKR1C3 shares up to $86 \%$ identity to its homologs, AKR1C2 and AKR1C1, that inactivate DHT in the prostate (Penning et al. 2000). Nevertheless, some compounds, including indomethacin (Bauman et al. 2005), ASP952 (Kikuchi et al. 2014) and GTx-560 (Yepuru et al. 2013) inhibit AKR1C3 activity with strong selectivity over AKR1C1 and AKR1C2. The compounds have provided promising results in preclinical studies in vivo, thus, being possible future CRPC therapies. Recently, also CYP11A1 inhibitors have been developed toward reducing local androgen biosynthesis in patients with CRPC (Oksala et al. 2017).

\section{VCaP xenografts as a preclinical model for prostate cancer}

Androgen biosynthesis in $\mathrm{PCa}$ is a complex process, regulated by multiple organ interactions. Thus, cell-based models or even primary tissue cultures in vitro are not able to well-mimic the physiology typically involved in intratumoral androgen biosynthesis. The benefit of the in vivo models is evident, due to the presence of the blood circulation delivering the active androgens and their precursors potentially synthesized by other organs, and due to the presence of the regulatory systems involving multiple endocrine organs and their interactions, including but not limited to the pituitary, adrenals and testes. Thus, still to date, xenograft studies carried out by grafting established PCa cell lines in immunodeficient mice is a highly appropriate method to model intratumoral androgen biosynthesis and metabolism in PCa. These studies aid drug development and help us to understand the growth mechanisms of primary $\mathrm{PCa}$, as well as to model the hormone dependency of CRPC growth. At best, these studies, complemented with studies on androgen profiles in clinical samples obtained from PCa patients, are highly valuable in order to identify mechanisms of androgen biosynthesis during the different disease stages and drug interventions.

One of the PCa models utilized by us and others, both in vitro and in vivo, is based on VCaP PCa cells. The cell line was originally derived from a vertebral metastatic lesion of a patient with hormone refractory PCa (Korenchuk et al. 2001). The VCaP cells are androgen-dependent and express several characteristics typical to human PCa. For example, the VCaP cells secrete PSA, and express wild-type $A R$ as well as several of the AR splice variants typically present in clinical PCa. Furthermore, similar to advanced $\mathrm{PCa}$, the $A R$ gene is amplified in the VCaP cells, resulting to a high expression of both AR mRNA and protein (van Bokhoven et al. 2003, Knuuttila et al. 2014). The VCaP cells are suitable for efficient tumor establishment in vivo due to high take rate when engrafted either subcutaneously or orthotopically in the prostate (Korenchuk et al. 2001, Knuuttila et al. 2014). Even more importantly, the VCaP cells grow in intact mice in androgen-sensitive manner, while castration induces a transient reduction in growth rate and a dramatic drop in the PSA secretion (Fig. 1). However, within a few weeks after castration, the tumor growth recurs, mimicking the castration-resistant growth of clinical tumors (Loberg et al. 2006, Knuuttila et al. 2014, Moilanen et al. 2015, Oksala et al. 2018).

In contrast to most of the PCa cell lines, including the often used models based on PC-3, LNCaP and DU145 cells, the VCaP cells contain the TMPRSS2-ERG fusion gene that is a hallmark of up to $50 \%$ of the PCas. Even though, the final role of the oncogenic TMPRSS2-ERG fusion gene in PCa remains to be determined, it has been shown to result in overexpression of the ERG oncoprotein that, in turn, has been proposed to lead into epithelialto-mesenchymal transition and to increased migration and invasion (Archer et al. 2017). Furthermore, compared to LNCaP and C4-2 cells, VCaP cells express higher levels of steroidogenic enzymes that are associated with the androgen biosynthesis of clinical CRPC, including AKR1C3, CYP11A1, HSD17B3, HSD17B6, HSD3B2 and SRD5A1 (Cai et al. 2011). The above described features of the VCaP cell line make it an appropriate model for studying intratumoral androgen biosynthesis in the different stages of PCa (Fig. 1).

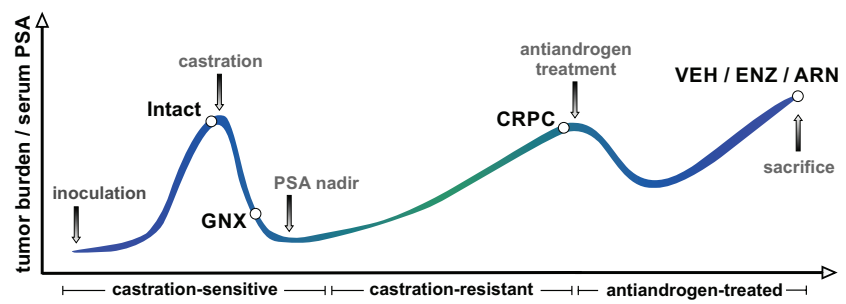

\section{Figure 1}

A timeline of the VCaP xenograft growth in nude mice followed by serum PSA, resembling the stages of clinical CRPC. The tumors are inoculated in intact mice, and after 4-5 weeks the tumors are established. The castration causes a dramatic drop in serum PSA, but recurrence of the tumors is observed within 5-6 weeks. After the establishment of the castration-resistant tumors, a response to antiandrogens (ARN, ARN-509; ENZ, enzalutamide) is observed; however, the response seems to be transient. 


\section{Androgen action and androgen metabolism in VCaP prostate cancer xenografts}

As expected, in our studies with the $\mathrm{VCaP}$ xenograft model, castration markedly decreased both serum and intratumoral levels of all the classical androgens, A-dione, $\mathrm{T}$ and DHT (Knuuttila et al. 2014, 2018a, Huhtaniemi et al. 2018). However, this decrease was transient, and significant concentrations of $\mathrm{T}$ and DHT were measured with the LC-MS/MS and GC-MS/MS in the castrationresistant $\mathrm{VCaP}$ tumors, despite the very low levels in the circulation. This observation was considered as a strong indication of intratumoral androgen biosynthesis, being evidently independent of gonadal androgen production. While we did not find significant levels of CYP17A1 in the VCaP xenografts (Knuuttila et al. 2014), indicating that the intratumoral $\mathrm{T}$ and DHT in these mice are synthesized from adrenal precursors, also de novo androgen biosynthesis in the VCaP tumors has been proposed (Cai et al. 2011). Also castration-resistant metastases in patients have shown to express the key enzymes essential for the conversion of progestins to adrenal androgens, and to their further conversion to $\mathrm{T}$ (Montgomery et al. 2008), while in this study the DHT/T ratio in the metastases was found to be reduced compared to the intact tumors. Interestingly, this study, similarly to ours (Knuuttila et al. 2018b), indicated higher levels of $\mathrm{T}$ and DHT in primary prostate cancers compared with paired benign prostate tissues in eugonadal men.

Studies on intratumoral androgen biosynthesis in $\mathrm{PCa}$, especially in CRPC, have indicated the presence of several pathways for DHT synthesis (Fig. 2), named canonical, alternative and backdoor pathways (Chang et al. 2011, Fiandalo et al. 2014, Penning 2014, Stuchbery et al. 2017, Mohler 2018). However, all these three pathways are still expected to require the classical enzymes at the early synthesis steps, including CYP11A1, HSD3B2 and CYP17A1. Nevertheless, our global gene

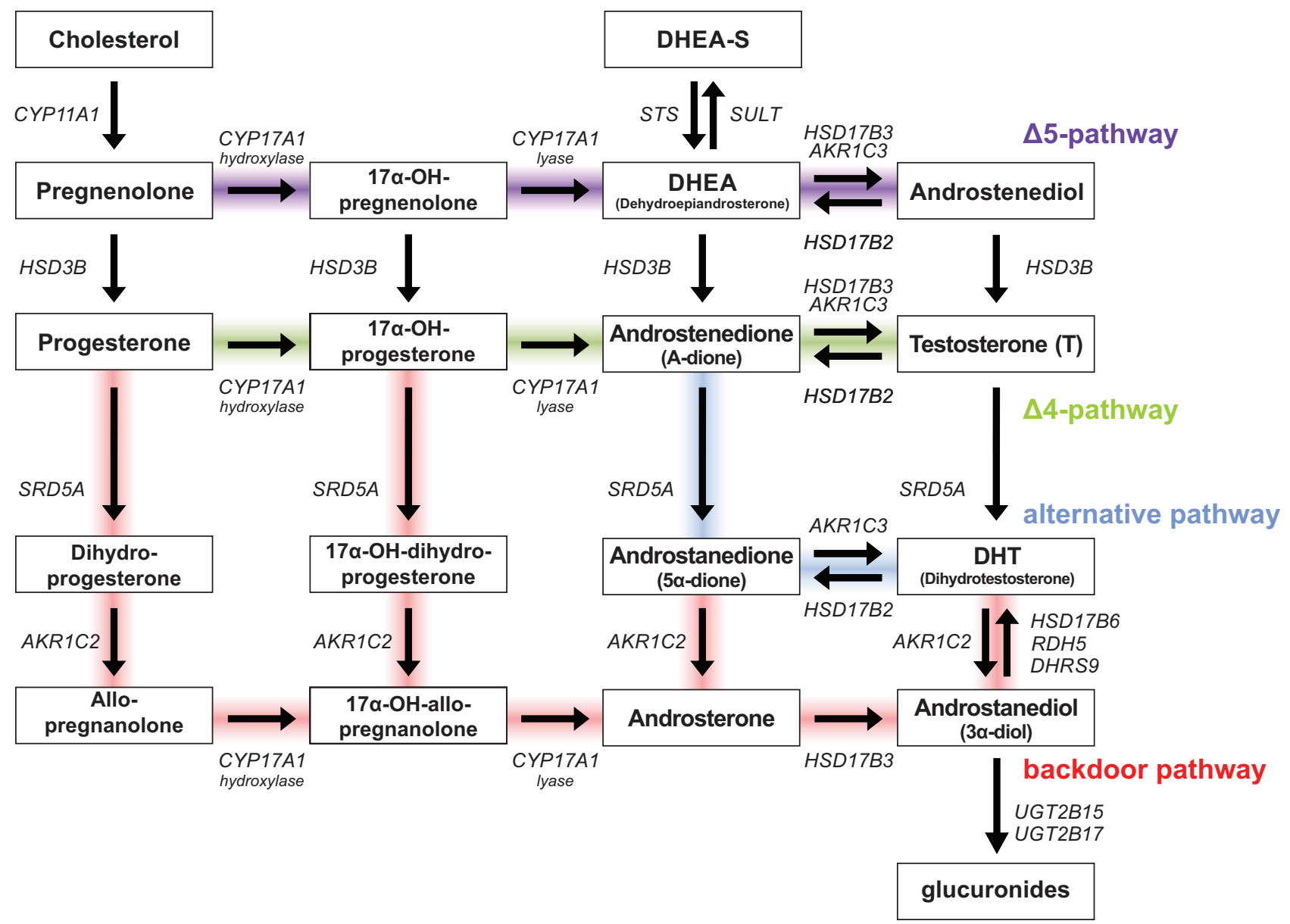

Figure 2

Potential pathways including the canonical $\Delta 4$ and $\Delta 5$ pathways, alternative pathway and backdoor pathway for the synthesis and metabolism of DHT in prostate cancer, involving both classical and more novel enzymes with steroid-metabolizing activity. 
expression profiling showed that these enzymes were not substantially expressed in the castration-resistant VCaP tumors (Knuuttila et al. 2014). The lack of these enzymes essential for de novo androgen biosynthesis, together with the MS data indicating measurable levels of A-dione and progesterone in serum of castrated mice (Knuuttila et al. 2014), further suggest that the androgens present in the castration-resistant VCaP tumors are, at least partially, synthesized from the precursors of adrenal origin. In line with this, our recent data have shown a reduced growth rate and an antiandrogenic effect in target gene expression in castration-resistant VCaP tumors after adrenalectomy (Huhtaniemi et al. 2018).

Particularly, the DHT concentrations were high in the castration-resistant VCaP tumors, whereas the intratumoral $\mathrm{T}$ concentrations were clearly lower (Knuuttila et al. 2014). We, thus, hypothesize that DHT synthesis in these tumors applies a pathway, being independent of $\mathrm{T}$ as an intermediate. Also in other MS-based studies T-independent conversion of A-dione to DHT via androstanedione has been demonstrated to be the predominant route for DHT formation in CRPC (Chang et al. 2011, Dai et al. 2017), while both T-dependent and independent DHT formation are equally used in the primary tumors (Dai et al. 2017). Similarly to that observed in VCaP xenografts, intratumoral DHT concentration was retained or increased, after castration in $80 \%(14 / 18)$ of the LuCaP xenografts tested, while T was decreased, suggesting intratumoral DHT synthesis also in majority of these castration-resistant patientderived xenografts (Nguyen et al. 2017). Furthermore, it has been shown that the conversion from A-dione to androstanedione is preferably mediated by SRD5A1 and not by SRD5A2 that is the major $5 \alpha$-reductase present in the benign prostate (Luu-The et al. 2008, Chang et al. 2011). Interestingly, SRD5A1 is also expressed in the castration-resistant VCaP tumors, while no SRD5A2 expression was detected in these tumors. It is also worth noting that A-dione and $\mathrm{T}$ do not present with substrate competition in a $5 \alpha$-reductase activity assay applied on cultured prostatic tissue ex vivo (Dai et al. 2017).

Our recent studies have indicated that the expression of steroidogenic enzymes AKR1C3 and HSD17B6 are upregulated in the castration-resistant $\mathrm{VCaP}$ tumors. The activity of AKR1C3 has been frequently associated with the progression of CRPC, thus, it has become a potential novel target for developing inhibitors for intratumoral androgen biosynthesis (Stanbrough et al. 2006, Pfeiffer et al. 2011, Powell et al. 2015). Similar to HSD17B3, AKR1C3 catalyzes the conversion of A-dione and androstanedione to $\mathrm{T}$ and
DHT, respectively. The expression of $A K R 1 C 3$ is abundant in the castration-resistant VCaP tumors, while HSD17B3 is absent in VCaP cells. Thus, of these two reductive HSD17B enzymes, AKR1C3 is more likely involved in the DHT synthesis in castration-resistant VCaP tumors, either via classical or other pathways (Fig. 2). Alike, HSD17B6 has been suggested to have an important role in the DHT synthesis in CRPC by converting androstanediol to DHT (Bauman et al. 2006, Mohler et al. 2011a,b), however, its enzymatic properties are only poorly characterized. In conclusion, the MS data on steroids suggest that a testosterone-independent pathway is the preferred pathway for DHT synthesis in the castration-resistant VCaP tumors. Further studies with a broader profile of steroids, including the backdoor pathway metabolites, should be conducted using MS-based assays to fully confirm the required androgen biosynthesis machinery in this preclinical CRPC model.

\section{Intratumoral androgen levels are reduced in antiandrogen-treated VCaP tumors}

The use of the first potent antiandrogens developed several decades ago has been limited due to severe side effects and interactions with other steroid receptors. However, enzalutamide, a second-generation antiandrogen, has been approved by FDA for the treatment of CRPC. Enzalutamide possesses numerous improved properties compared to the first-generation compounds: it binds to the AR with a greater affinity, blocks the AR more effectively, impairs the ability of the receptor to bind DNA and reduces the nuclear translocation of AR (Tran et al. 2009). A similar strong antiandrogenic efficacy is associated with ARN-509 (apalutamide), a derivate of enzalutamide (Clegg et al. 2012). Apalutamide has demonstrated antitumor activity in nonmetastatic CRPC patients (Smith et al. 2016). In addition, another novel antiandrogen has been recently developed (ODM-201, darolutamide) that has passed successfully phase 1 and 2 trials (Fizazi et al. 2014). Importantly, ODM-201 has been demonstrated to block also the action of several AR mutants, such as F876L, thus, having additional features over those present in enzalutamide and ARN-509 (Moilanen et al. 2015, Borgmann et al. 2018). Partly due to the discovery of AR splice variants that lack the ligandbinding domain (LBD), the need for antiandrogens that target other parts of AR than LBD has also emerged.

To further improve the treatment outcome of patients with CRPC, we have to understand in detail the mechanisms of action of these new antiandrogens. 
Interestingly, our recent data obtained by the GC-MS/ MS (Fig. 3) demonstrated that antiandrogen treatment for 4 weeks markedly reduced the levels of intratumoral $\mathrm{T}$ and DHT in the castration-resistant VCaP xenografts (Knuuttila et al. 2018a). This interesting observation could be a result of different mechanisms, one possibility being a direct or indirect effect of the antiandrogens on the intratumoral androgen biosynthesis. This is supported by the observation that treatments with enzalutamide and ARN-509 altered the expression of several steroidogenic enzymes, including AKR1C2, AKR1C3 and HSD17B6. Of these, AKR1C3 is best characterized, and it has been associated with DHT synthesis in CRPC in several studies, as described above. Furthermore, AKR1C2 has been shown to metabolize DHT to a weak androgenic 3 $\alpha$-diol (Bauman et al. 2006), and thus, the reduced DHT concentrations measured could be a result of enhanced conversion of DHT to androstanediol (Fig. 2), a metabolite that could not be detected with high enough sensitivity with our currently available LC-MS/MS or GC-MS/MS methods. Moreover, HSD17B6 has been often associated with DHT metabolism (Ishizaki et al. 2013), while its enzymatic properties are still to be better characterized (Zhang et al. 2016). There is also a possibility that these antiandrogens inhibit steroidogenic enzymes directly by competing at the active site with the substrates. This hypothesis
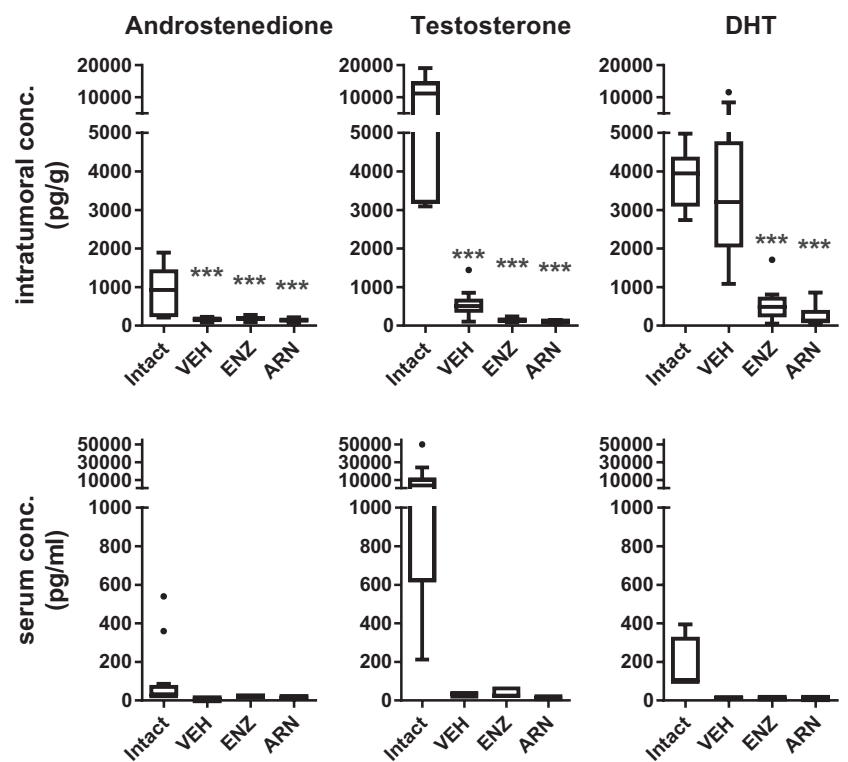

\section{Figure 3}

Intratumoral and serum androgen concentrations of VCaP tumors measured by GC-MS (modified from Knuuttila et al. 2014 and 2018a). ARN, castration-resistant tumors treated for 4 weeks with ARN-509 $(20 \mathrm{mg} / \mathrm{kg}$ / day); ENZ, castration-resistant tumors treated for 4 weeks with enzalutamide (20 mg/kg/day); Intact, tumors grown in intact mice; $\mathrm{VEH}$, castration-resistant tumors. is supported by the findings showing that a metabolite of abiraterone possesses antiandrogenic properties by binding directly to AR (Li et al. 2015).

While the VCaP model displays several hallmarks of CRPC, presently it is not known whether the effects of antiandrogens on intratumoral androgen levels translate into clinical CRPC. However, a recent study demonstrated that patients treated for 3 months with GnRH agonist or antagonist combined with antiandrogen (bicalutamide) prior to radical prostatectomy were associated with lower intratumoral DHT levels measured by LC-MS/MS compared to the patients who were treated with one of the GnRH antagonists only (Sayyid et al. 2017). No differences in the intratumoral $\mathrm{T}$ levels were observed between the treatment groups in this study. However, the lack of sensitivity in the MS assay used might have affected the results. In summary, the data suggest that AR blockade alters androgen metabolism in the castrationresistant VCaP xenograft tumors by a yet unidentified mechanism, and further studies are needed to elucidate if these findings translate to clinical CRPC.

\section{Declaration of interest}

The authors declare that there is no conflict of interest that could be perceived as prejudicing the impartiality of this review.

\section{Funding}

This research did not receive any specific grant from any funding agency in the public, commercial or not-for-profit sector.

\section{References}

Archer LK, Frame FM \& Maitland NJ 2017 Stem cells and the role of ETS transcription factors in the differentiation hierarchy of normal and malignant prostate epithelium. Journal of Steroid Biochemistry and Molecular Biology 166 68-83. (https://doi.org/10.1016/j. jsbmb.2016.05.006)

Arlt W, Biehl M, Taylor AE, Hahner S, Libé R, Hughes BA, Schneider P, Smith DJ, Stiekema H, Krone N, et al. 2011 Urine steroid metabolomics as a biomarker tool for detecting malignancy in adrenal tumors. Journal of Clinical Endocrinology and Metabolism 96 3775-3784. (https://doi.org/10.1210/jc.2011-1565)

Attard G, Belldegrun AS \& de Bono JS 2005 Selective blockade of androgenic steroid synthesis by novel lyase inhibitors as a therapeutic strategy for treating metastatic prostate cancer. BJU International 96 1241-1246. (https://doi. org/10.1111/j.1464-410X.2005.05821.x)

Banerjee PP, Banerjee S, Brown TR \& Zirkin BR 2018 Androgen action in prostate function and disease. American Journal Clinic Expérimentale Urologia 6 62-77.

Bauman DR, Rudnick SI, Szewczuk LM, Jin Y, Gopishetty S \& Penning TM 2005 Development of nonsteroidal anti-inflammatory drug analogs and steroid carboxylates selective for human aldo-keto reductase isoforms: potential antineoplastic agents that work 
independently of cyclooxygenase isozymes. Molecular Pharmacology 67 60-68. (https://doi.org/10.1124/mol.104.006569)

Bauman DR, Steckelbroeck S, Williams MV, Peehl DM \& Penning TM 2006 Identification of the major oxidative 3alpha-hydroxysteroid dehydrogenase in human prostate that converts 5alpha-androstane3alpha,17beta-diol to 5alpha-dihydrotestosterone: a potential therapeutic target for androgen-dependent disease. Molecular Endocrinology 20 444-458. (https://doi.org/10.1210/me.2005-0287)

Bayliss MK, Little D, Mallett DN \& Plumb RS 2000 Parallel ultra-high flow rate liquid chromatography with mass spectrometric detection using a multiplex electrospray source for direct, sensitive determination of pharmaceuticals in plasma at extremely high throughput. Rapid Communications in Mass Spectrometry 14 2039-2045. (https://doi.org/10.1002/1097-

0231(20001115)14:21<2039::AID-RCM130>3.0.CO;2-2)

Bélanger B, Fiet J \& Bélanger A 1993 Effects of adrenocorticotropin on adrenal and plasma 11 -hydroxyandrostenedione in the guinea pig and determination of its relative androgen potency. Steroids $\mathbf{5 8}$ 29-34. (https://doi.org/10.1016/0039-128X(93)90014-E)

Bergeron A, Furtado M \& Garofolo F 2009 Importance of using highly pure internal standards for successful liquid chromatography/tandem mass spectrometric bioanalytical assays. Rapid Communications in Mass Spectrometry 23 1287-1297. (https://doi.org/10.1002/rcm.4001)

Bloem LM, Storbeck KH, Schloms L \& Swart AC 2013

$11 \beta$-Hydroxyandrostenedione returns to the steroid arena: biosynthesis, metabolism and function. Molecules 18 13228-13244. (https://doi.org/10.3390/molecules181113228)

Boggs ASP, Bowden JA, Galligan TM Jr, Guillette LJ \& Kucklick JR 2016 Development of a multi-class steroid hormone screening method using Liquid Chromatography/Tandem Mass Spectrometry (LC-MS/ MS). Analytical and Bioanalytical Chemistry 408 4179-4190. (https:// doi.org/10.1007/s00216-016-9512-1)

Borgmann H, Lallous N, Ozistanbullu D, Beraldi E, Paul N, Dalal K, Fazli L, Haferkamp A, Lejeune P, Cherkasov A, et al. 2018 Moving towards precision urologic oncology: targeting enzalutamideresistant prostate cancer and mutated forms of the androgen receptor using the novel inhibitor darolutamide (ODM-201). European Urology 73 4-8. (https://doi.org/10.1016/j. eururo.2017.08.012)

Bronsema KJ, Bischoff R \& Van de Merbel NC 2012 Internal standards in the quantitative determination of protein biopharmaceuticals using liquid chromatography coupled to mass spectrometry. Journal of Chromatography. B, Analytical Technologies in the Biomedical and Life Sciences 893-894 1-14. (https://doi.org/10.1016/j. jchromb.2012.02.021)

Byrns MC, Jin Y \& Penning TM 2011 Inhibitors of type 5 17 $\beta$-hydroxysteroid dehydrogenase (AKR1C3): overview and structural insights. Journal of Steroid Biochemistry and Molecular Biology 125 95-104. (https://doi.org/10.1016/j.jsbmb.2010.11.004)

Byrns MC, Mindnich R, Duan L \& Penning TM 2012 Overexpression of aldo-keto reductase 1C3 (AKR1C3) in LNCaP cells diverts androgen metabolism towards testosterone resulting in resistance to the $5 \alpha$-reductase inhibitor finasteride. Journal of Steroid Biochemistry and Molecular Biology 130 7-15. (https://doi.org/10.1016/j. jsbmb.2011.12.012)

Cai C, Chen S, Ng P, Bubley GJ, Nelson PS, Mostaghel EA, Marck B, Matsumoto AM, Simon NI, Wang H, et al. 2011 Intratumoral de novo steroid synthesis activates androgen receptor in castrationresistant prostate cancer and is upregulated by treatment with CYP17A1 inhibitors. Cancer Research 71 6503-6513. (https://doi. org/10.1158/0008-5472.CAN-11-0532)

Cha EK \& Shariat SF 2011 The use of $5 \alpha$-reductase inhibitors for the prevention and treatment of prostate cancer. European Urology 59 515-517. (https://doi.org/10.1016/j.eururo.2011.01.028)

Chang KH, Li R, Papari-Zareei M, Watumull L, Zhao YD, Auchus RJ \& Sharifi N 2011 Dihydrotestosterone synthesis bypasses testosterone to drive castration-resistant prostate cancer. PNAS 108 13728-13733. (https://doi.org/10.1073/pnas.1107898108)

Clark RV, Hermann DJ, Cunningham GR, Wilson TH, Morrill BB \& Hobbs S 2004 Marked Suppression of dihydrotestosterone in Men with benign prostatic Hyperplasia by dutasteride, a dual $5 \alpha$-reductase Inhibitor. Journal of Clinical Endocrinology and Metabolism 89 2179-2184. (https://doi.org/10.1210/jc.2003-030330)

Clegg NJ, Wongvipat J, Joseph JD, Tran C, Ouk S, Dilhas A, Chen Y, Grillot K, Bischoff ED, Cai L, et al. 2012 ARN-509: a novel antiandrogen for prostate cancer treatment. Cancer Research 72 1494-1503. (https://doi.org/10.1158/0008-5472.CAN-11-3948)

Coutinho I, Day TK, Tilley WD \& Selth LA 2016 Androgen receptor signaling in castration-resistant prostate cancer: a lesson in persistence. Endocrine-Related Cancer 23 T179-T197. (https://doi. org/10.1530/ERC-16-0422)

Cross TG \& Hornshaw MP 2016 Can LC and LC-MS ever replace immunoassays? Journal of Applied Bioanalysis 2 108-116. (https://doi. org/10.17145/jab.16.015)

Dai C, Chung YM, Kovac E, Zhu Z, Li J, Magi-Galluzzi C, Stephenson AJ, Klein EA \& Sharifi N 2017 Direct metabolic interrogation of dihydrotestosterone biosynthesis from adrenal precursors in primary prostatectomy tissues. Clinical Cancer Research 23 6351-6362. (https://doi.org/10.1158/1078-0432.CCR-17-1313)

de Bono JS, Logothetis CJ, Molina A, Fizazi K, North S, Chu L, Chi KN, Jones RJ, Goodman OB Jr, Saad F, et al. 2011 Abiraterone and increased survival in metastatic prostate cancer. New England Journal of Medicine 364 1995-2005. (https://doi.org/10.1056/ NEJMoa1014618)

du Toit T, Bloem LM, Quanson JL, Ehlers R, Serafin AM \& Swart AC 2017 Profiling adrenal 11beta-hydroxyandrostenedione metabolites in prostate cancer cells, tissue and plasma: UPC2-MS/MS quantification of 11beta-hydroxytestosterone, 11keto-testosterone and 11keto-dihydrotestosterone. Journal of Steroid Biochemistry and Molecular Biology 166 54-67. (https://doi.org/10.1016/j. jsbmb.2016.06.009)

Taylor AE, Keevil B \& Huhtaniemi IT 2015 Mass spectrometry and immunoassay: how to measure steroid hormones today and tomorrow. European Journal of Endocrinology 173 1-12. (https://doi. org/10.1530/EJE-15-0338)

Fiandalo MV, Wilton J \& Mohler JL 2014 Roles for the backdoor pathway of androgen metabolism in prostate cancer response to castration and drug treatment. International Journal of Biological Sciences 10 596-601. (https://doi.org/10.7150/ijbs.8780)

Fizazi K, Massard C, Bono P, Jones R, Kataja V, James N, Garcia JA, Protheroe A, Tammela TL, Elliott T, et al. 2014 Activity and safety of ODM-201 in patients with progressive metastatic castration-resistant prostate cancer (ARADES): an open-label phase 1 dose-escalation and randomised phase 2 dose expansion trial. Lancet Oncology 15 975-985. (https://doi.org/10.1016/S1470-2045(14)70240-2)

Häkkinen MR, Heinosalo T, Saarinen-Aaltonen N, Linnanen T, Koskimies P, Voutilainen R, Lakka T, Jääskeläinen J, Poutanen M \& Auriola S 2018 Analysis of steroids from human serum, plasma, endometrium and endometriosis tissues by LC-MS/MS. Journal of Pharmaceutical and Biomedical Analysis 152 165-172. (https://doi. org/10.1016/j.jpba.2018.01.034)

Handelsman DJ 2017 Mass spectrometry, immunoassay and valid steroid measurements in reproductive medicine and science. Human Reproduction 32 1147-1150. (https://doi.org/10.1093/humrep/ dex078)

Handelsman DJ \& Wartofsky L 2013 Requirement for mass spectrometry sex steroid assays in the journal of clinical endocrinology and metabolism. Journal of Clinical Endocrinology and Metabolism 99 4434-4437. (https://doi.org/10.1210/jc.2013-3375)

Harwood DT \& Handelsman DJ 2009 Development and validation of a sensitive liquid chromatography-tandem mass spectrometry assay to simultaneously measure androgens and estrogens in serum without 
derivatization. Clinica Chimica Acta 409 78-84. (https://doi. org/10.1016/j.cca.2009.09.003)

Huhtaniemi I, Nikula H \& Rannikko S 1985 Treatment of prostatic cancer with a gonadotropin-releasing hormone agonist analog: acute and long term effects on endocrine functions of testis tissue. Journal of Clinical Endocrinology and Metabolism 61 698-704. (https://doi. org/10.1210/jcem-61-4-698)

Huhtaniemi R, Oksala R, Knuuttila M, Mehmood A, Aho E, Laajala TD, Nicorici D, Aittokallio T, Laiho A, Elo L, et al. 2018 Adrenals contribute to growth of castration-resistant VCaP prostate cancer xenografts. American Journal of Pathology 188 2890-2901. (https:// doi.org/10.1016/j.ajpath.2018.07.029)

Husen B, Huhtinen K, Saloniemi T, Messinger J, Thole HH \& Poutanen M 2006 Human hydroxysteroid (17-beta) dehydrogenase 1 expression enhances estrogen sensitivity of MCF-7 breast cancer cell xenografts. Endocrinology 147 5333-5339. (https://doi.org/10.1210/ en.2006-0778)

Imamichi Y, Yuhki KI, Orisaka M, Kitano T, Mukai K, Ushikubi F, Taniguchi T, Umezawa A, Miyamoto K \& Yazawa T 2016 11-ketotestosterone is a major androgen produced in human gonads. Journal of Clinical Endocrinology and Metabolism 101 3582-3591. (https://doi.org/10.1210/jc.2016-2311)

Ishizaki F, Nishiyama T, Kawasaki T, Miyashiro Y, Hara N, Takizawa I, Naito M \& Takahashi K 2013 Androgen deprivation promotes intratumoral synthesis of dihydrotestosterone from androgen metabolites in prostate cancer. Scientific Reports 3 1528. (https://doi. org/10.1038/srep01528)

Jannetto PJ \& Fitzgerald RL 2016 Effective use of mass spectrometry in the clinical laboratory. Clinical Chemistry 62 92-98. (https://doi. org/10.1373/clinchem.2015.248146)

Jin Y \& Penning TM 2007 Aldo-keto reductases and bioactivation/ detoxication. Annual Review of Pharmacology and Toxicology 47 263-292. (https://doi.org/10.1146/annurev. pharmtox.47.120505.105337)

Ke Y, Gonthier R, Isabelle M, Bertin J, Simard JN, Dury AY \& Labrie F 2015 A rapid and sensitive UPLC-MS/MS method for the simultaneous quantification of serum androsterone glucuronide, etiocholanolone glucuronide, and androstan- $3 \alpha, 17 \beta$ diol 17-glucuronide in postmenopausal women. Journal of Steroid Biochemistry and Molecular Biology 149 146-152. (https://doi. org/10.1016/j.jsbmb.2015.02.009)

Keski-Rahkonen P, Huhtinen K, Poutanen M \& Auriola S 2011 Fast and sensitive liquid chromatography-mass spectrometry assay for seven androgenic and progestagenic stroids in human serum. Journal of Steroid Biochemistry and Molecular Biology 127 396-404. (https://doi. org/10.1016/j.jsbmb.2011.06.006)

Keski-Rahkonen P, Huhtinen K, Harwood DT, Handelsman DJ, Poutanen M \& Auriola S 2013 Comparison of electrospray ionization, atmospheric pressure chemical ionization, and atmospheric pressure photoionization for the analysis of estradiol in human serum and endometrium. Journal of Mass Spectrometry $\mathbf{4 8}$ 1050-1058. (https://doi.org/10.1002/jms.3252)

Kikuchi A, Furutani T, Azami H, Watanabe K, Niimi T, Kamiyama Y, Kuromitsu S, Baskin-Bey E, Heeringa M, Ouatas T, et al. 2014 In vitro and in vivo characterisation of ASP9521: A novel, selective, orally bioavailable inhibitor of $17 \beta$-hydroxysteroid dehydrogenase type 5 (17ßHSD5; AKR1C3). Investigational New Drugs 32 860-870. (https:// doi.org/10.1007/s10637-014-0130-5)

Kim EH, Brockman JA \& Andriole GL 2018 The use of 5-alpha reductase inhibitors in the treatment of benign prostatic hyperplasia. Asian Journal of Urology 5 28-32. (https://doi.org/10.1016/j. ajur.2017.11.005)

Knuuttila M, Yatkin E, Kallio J, Savolainen S, Laajala TD, Aittokallio T, Oksala R, Häkkinen M, Keski-Rahkonen P, Auriola S, et al. 2014 Castration induces up-regulation of intratumoral androgen biosynthesis and androgen receptor expression in an orthotopic
VCaP human prostate cancer xenograft model. American Journal of Pathology 184 2163-2173. (https://doi.org/10.1016/j. ajpath.2014.04.010)

Knuuttila M, Mehmood A, Huhtaniemi R, Yatkin E, Häkkinen MR, Oksala R, Laajala TD, Ryberg H, Handelsman DJ, Aittokallio T, et al. $2018 a$ Antiandrogens reduce intratumoral androgen concentrations and induce androgen receptor expression in castration-resistant prostate cancer xenografts. American Journal of Pathology 188 216-228. (https://doi.org/10.1016/j. ajpath.2017.08.036)

Knuuttila M, Mehmood A, Mäki-Jouppila J, Ryberg H, Taimen P, Knaapila J, Ettala O, Boström PJ, Ohlsson C, Venäläinen MS, et al. $2018 b$ Intratumoral androgen levels are linked to TMPRSS2-ERG fusion in prostate cancer. Endocrine-Related Cancer 25 807-819. (https://doi.org/10.1530/ERC-18-0148)

Korenchuk S, Lehr JE, MClean L, Lee YG, Whitney S, Vessella R, Lin DL \& Pienta KJ 2001 VCaP, a cell-based model system of human prostate cancer. In Vivo 15 163-168.

Labrie F 1991 Intracrinology. Molecular and Cellular Endocrinology 78 C113-C118. (https://doi.org/10.1016/0303-7207(91)90116-A)

Lacy JM \& Kyprianou N 2014 A tale of two trials: the impact of $5 \alpha$-reductase inhibition on prostate cancer (Review). Oncology Letters 8 1391-1396. (https://doi.org/10.3892/ol.2014.2388)

Laurent MR, Hammond GL, Blokland M, Jardí F, Antonio L, Dubois V, Khalil R, Sterk SS, Gielen E, Decallonne B, et al. 2016 Sex hormonebinding globulin regulation of androgen bioactivity in vivo: validation of the free hormone hypothesis. Scientific Reports 635539. (https://doi.org/10.1038/srep35539)

Li Z, Bishop AC, Alyamani M, Garcia JA, Dreicer R, Bunch D, Liu J, Upadhyay SK, Auchus RJ \& Sharifi N 2015 Conversion of abiraterone to D4A drives anti-tumour activity in prostate cancer. Nature $\mathbf{5 2 3}$ 347-351. (https://doi.org/10.1038/nature14406)

Liere P \& Schumacher M 2015 Mass spectrometric analysis of steroids: all that glitters is not gold. Expert Review of Endocrinology and Metabolism 10 463-465. (https://doi.org/10.1586/17446651.2015.10 63997)

Loberg RD, St John LN, Day LL, Neeley CK \& Pienta KJ 2006 Development of the VCaP androgen-independent model of prostate cancer. Urologic Oncology 24 161-168. (https://doi.org/10.1016/j. urolonc.2005.11.005)

Luu-The V, Bélanger A \& Labrie F 2008 Androgen biosynthetic pathways in the human prostate. Best Practice and Research. Clinical Endocrinology and Metabolism 22 207-221. (https://doi.org/10.1016/j. beem.2008.01.008)

Matsushita S, Suzuki K, Murashima A, Kajioka D, Acebedo AR, Miyagawa S, Haraguchi R, Ogino Y \& Yamada G 2018 Regulation of masculinization: androgen signalling for external genitalia development. Nature Reviews Urology 15 358-368. (https://doi. org/10.1038/s41585-018-0008-y)

Mendonca BB, Batista RL, Domenice S, Costa EM, Arnhold IJ Russell DW \& Wilson JD 2017 Reprint of 'Steroid $5 \alpha$-reductase 2 deficiency'. Journal of Steroid Biochemistry and Molecular Biology 165 95-100. (https://doi.org/10.1016/j.jsbmb.2016.11.006)

Miller WL 2017 Steroidogenesis: unanswered questions. Trends in Endocrinology and Metabolism 28 771-793. (https://doi.org/10.1016/j. tem.2017.09.002)

Mohler JL 2018 A brief history of intracrine androgen metabolism by castration-recurrent prostate cancer. American Journal of Clinical and Experimental Urology 6 101-106.

Mohler JL, Titus MA \& Wilson EM 2011a Potential prostate cancer drug target: bioactivation of androstanediol by conversion to dihydrotestosterone. Clinical Cancer Research 17 5844-5849. (https:// doi.org/10.1158/1078-0432.CCR-11-0644)

Mohler JL, Titus MA, Bai S, Kennerley BJ, Lih FB, Tomer KB \& Wilson EM $2011 b$ Activation of the androgen receptor by intratumoral bioconversion of androstanediol to dihydrotestosterone https://jme.bioscientifica.com

https://doi.org/10.1530/JME-18-0150 (c) 2019 Society for Endocrinology Published by Bioscientifica Ltd. Printed in Great Britain 
in prostate cancer. Cancer Research 71 1486-1496. (https://doi. org/10.1158/0008-5472.CAN-10-1343)

Moilanen AM, Riikonen R, Oksala R, Ravanti L, Aho E, Wohlfahrt G, Nykänen PS, Törmäkangas OP, Palvimo JJ \& Kallio PJ 2015 Discovery of ODM-201, a new-generation androgen receptor inhibitor targeting resistance mechanisms to androgen signaling-directed prostate cancer therapies. Scientific Reports 5 12007. (https://doi.org/10.1038/ srep12007)

Montgomery RB, Mostaghel EA, Vessella R, Hess DL, Kalhorn TF, Higano CS, True LD \& Nelson PS 2008 Maintenance of intratumoral androgens in metastatic prostate cancer: a mechanism for castrationresistant tumor growth. Cancer Research 68 4447-4454. (https://doi. org/10.1158/0008-5472.CAN-08-0249)

Nebert DW, Wikvall K \& Miller WL 2013 Human cytochromes P450 in health and disease. Philosophical Transactions of the Royal Society of London. Series B, Biological Sciences 368 20120431. (https://doi. org/10.1098/rstb.2012.0431)

Neunzig J, Milhim M, Schiffer L, Khatri Y, Zapp J, Sánchez-Guijo A, Hartmann MF, Wudy SA \& Bernhardt R 2015 The steroid metabolite $16(\beta)-\mathrm{OH}$-androstenedione generated by CYP21A2 serves as a substrate for CYP19A1. Journal of Steroid Biochemistry and Molecular Biology 150 1-10. (https://doi.org/10.1016/j.jsbmb.2015.02.014)

Nguyen HM, Vessella RL, Morrissey C, Brown LG, Coleman IM, Higano CS, Mostaghel EA, Zhang X, True LD, Lam H-M, et al. 2017 LuCaP prostate cancer patient-derived xenografts reflect the molecular heterogeneity of advanced disease and serve as models for evaluating cancer therapeutics. Prostate 77 654-671. (https://doi. org/10.1002/pros.23313)

Nilsson ME, Vandenput L, Tivesten Å, Norlén AK, Lagerquist MK, Windahl SH, Börjesson AE, Farman HH, Poutanen M, Benrick A, et al. 2015 Measurement of a comprehensive sex steroid profile in rodent serum by high-sensitive gas chromatography-tandem mass spectrometry. Endocrinology 156 2492-2502. (https://doi.org/10.1210/ en.2014-1890)

O'Donnell A, Judson I, Dowsett M, Raynaud F, Dearnaley D, Mason M, Harland S, Robbins A, Halbert G, Nutley B, et al. 2004 Hormonal impact of the 17alpha-hydroxylase/C $(17,20)$-lyase inhibitor abiraterone acetate (CB7630) in patients with prostate cancer. British Journal of Cancer 90 2317-2325. (https://doi.org/10.1038/sj. bjc.6601879)

Oksala R, Karimaa M, Ramela M, Riikonen R, Huhtaniemi R, Rummakko P, Wohlfahrt G, Vuorela A, Mustonen M \& Kallio P 2017 ODM-208, a novel CYP11A1-inhibitor as a therapeutic approach for the treatment of castration-resistant prostate cancer. Annals of Oncology 28 (Supplement 5).

Oksala R, Moilanen A, Riikonen R, Rummakko P, Karjalainen A, Passiniemi M, Wohlfahrt G, Taavitsainen P, Malmström C, Ramela M, et al. 2018 Discovery and development of ODM-204: a novel nonsteroidal compound for the treatment of castrationresistant prostate cancer by blocking the androgen receptor and inhibiting CYP17A1. Journal of Steroid Biochemistry and Molecular Biology Epub. (https://doi.org/10.1016/j.jsbmb.2018.02.004)

Oppermann UC, Persson B, Filling C \& Jörnvall H 1997 Structurefunction relationships of SDR hydroxysteroid dehydrogenases. Advances in Experimental Medicine and Biology 414 403-415. (https:// doi.org/10.1007/978-1-4615-5871-2_46)

Penning TM 2014 Androgen biosynthesis in castration-resistant prostate cancer. Endocrine-Related Cancer 21 T67-T78. (https://doi. org/10.1530/ERC-14-0109)

Penning TM 2015 The aldo-keto reductases (AKRs): overview. ChemicoBiological Interactions 234 236-246. (https://doi.org/10.1016/j. cbi.2014.09.024)

Penning TM \& Drury JE 2007 Human aldo-keto reductases: function, gene regulation, and single nucleotide polymorphisms. Archives of Biochemistry and Biophysics 464 241-250. (https://doi.org/10.1016/j. abb.2007.04.024)
Penning TM, Burczynski ME, Jez JM, Hung CF, Lin HK, Ma H, Moore M, Palackal N \& Ratnam K 2000 Human 3alpha-hydroxysteroid dehydrogenase isoforms (AKR1C1-AKR1C4) of the aldo-keto reductase superfamily: functional plasticity and tissue distribution reveals roles in the inactivation and formation of male and female sex hormones. Biochemical Journal 351 67-77. (https://doi. org/10.1042/bj3510067)

Persson B, Hedlund J \& Jörnvall H 2008 Medium- and short-chain dehydrogenase/reductase gene and protein families: the MDR superfamily. Cellular and Molecular Life Sciences 65 3879-3894. (https://doi.org/10.1007/s00018-008-8587-z)

Pfeiffer MJ, Smit FP, Sedelaar JP \& Schalken JA 2011 Steroidogenic enzymes and stem cell markers are upregulated during androgen deprivation in prostate cancer. Molecular Medicine 17 657-664. (https://doi.org/10.2119/molmed.2010.00143)

Powell K, Semaan L, Conley-LaComb MK, Asangani I, Wu YM, Ginsburg KB, Williams J, Squire JA, Maddipati KR, Cher ML, et al. 2015 ERG/AKR1C3/AR constitutes a feed-forward loop for AR signaling in prostate cancer cells. Clinical Cancer Research $\mathbf{2 1}$ 2569-2579. (https://doi.org/10.1158/1078-0432.CCR-14-2352)

Pretorius E, Africander DJ, Vlok M, Perkins MS, Quanson J \& Storbeck KH 2016 11-ketotestosterone and 11-ketodihydrotestosterone in castration resistant prostate cancer: potent androgens which can no longer be ignored. PLoS One 11 e0159867. (https://doi.org/10.1371/journal.pone.0159867)

Ryan CJ, Smith MR, de Bono JS, Molina A, Logothetis CJ, de Souza P, Fizazi K, Mainwaring P, Piulats JM, Ng S, et al. 2013 Abiraterone in metastatic prostate cancer without previous chemotherapy. New England Journal of Medicine 368 138-148. (https://doi.org/10.1056/ NEJMoa1209096)

Ryan CJ, Peng W, Kheoh T, Welkowsky E, Haqq CM, Chandler DW, Scher HI \& Molina A 2014 Androgen dynamics and serum PSA in patients treated with abiraterone acetate. Prostate Cancer and Prostatic Diseases 17 192-198. (https://doi.org/10.1038/pcan.2014.8)

Santen RJ, Brodie H, Simpson ER, Siiteri PK \& Brodie A 2009 History of aromatase: saga of an important biological mediator and therapeutic target. Endocrine Reviews 30 343-375. (https://doi.org/10.1210/ er.2008-0016)

Savolainen S, Pakarainen T, Huhtaniemi I, Poutanen M \& Mäkelä S 2007 Delay of postnatal maturation sensitizes the mouse prostate to testosterone-induced pronounced hyperplasia: protective role of estrogen receptor-beta. American Journal of Pathology 171 1013-1022. (https://doi.org/10.2353/ajpath.2007.060979)

Sayyid RK, Evans A, Hersey K, Maloni R, Hurtado-Coll A, Kulkarni G, Finelli A, Zlotta AR, Hamilton R, Gleave M, et al. 2017 A phase II, randomized, open label study of neoadjuvant degarelix versus LHRH agonist in prostate cancer patients prior to radical prostatectomy. Clinical Cancer Research 23 1974-1980. (https://doi. org/10.1158/1078-0432.CCR-16-1790)

Schiffer L, Arlt W \& Storbeck KH 2018 Intracrine androgen biosynthesis, metabolism and action revisited. Molecular and Cellular Endocrinology 465 4-26. (https://doi.org/10.1016/j.mce.2017.08.016)

Simpson ER 2002 Aromatization of androgens in women: current concepts and findings. Fertility and Sterility 77 S6-S10. (https://doi. org/10.1016/S0015-0282(02)02984-9)

Smith MR, Antonarakis ES, Ryan CJ, Berry WR, Shore ND, Liu G, Alumkal JJ, Higano CS, Chow Maneval E, Bandekar R, et al. 2016 Phase 2 study of the safety and antitumor activity of apalutamide (ARN-509), a potent androgen receptor antagonist, in the highrisk nonmetastatic castration-resistant prostate cancer cohort. European Urology 70 963-970. (https://doi.org/10.1016/j. eururo.2016.04.023)

Snaterse G, Visser JA, Arlt W \& Hofland J 2016 Circulating steroid hormone variations throughout different stages of prostate cancer. Endocrine-Related Cancer 24 403-420. (https://doi.org/10.1530/ERC17-0155) 
Stanbrough M, Bubley GJ, Ross K, Golub TR, Rubin MA, Penning TM, Febbo PG \& Balk SP 2006 Increased expression of genes converting adrenal androgens to testosterone in androgen-independent prostate cancer. Cancer Research 66 2815-2825. (https://doi.org/10.1158/00085472.CAN-05-4000)

Storbeck KH, Bloem LM, Africander D, Schloms L, Swart P \& Swart AC 2013 11ß-Hydroxydihydrotestosterone and

11-ketodihydrotestosterone, novel C19 steroids with androgenic activity: a putative role in castration resistant prostate cancer? Molecular and Cellular Endocrinology 377 135-146. (https://doi. org/10.1016/j.mce.2013.07.006)

Stuchbery R, McCoy PJ, Hovens CM \& Corcoran NM 2017 Androgen synthesis in prostate cancer: do all roads lead to Rome? Nature Reviews Urology 14 49-58. (https://doi.org/10.1038/nrurol.2016.221)

Swart AC \& Storbeck KH 2015 11 $\beta$-hydroxyandrostenedione: downstream metabolism by $11 \beta \mathrm{HSD}, 17 \beta \mathrm{HSD}$ and SRD5A produces novel substrates in familiar pathways. Molecular and Cellular Endocrinology 408 114-123. (https://doi.org/10.1016/j. mce.2014.12.009)

Swart AC, Schloms L, Storbeck KH, Bloem LM, Toit TD, Quanson JL, Rainey WE \& Swart P 2013 11 $\beta$-Hydroxyandrostenedione, the product of androstenedione metabolism in the adrenal, is metabolized in LNCaP cells by $5 \alpha$-reductase yielding $11 \beta$-hydroxy- $5 \alpha$ androstanedione. Journal of Steroid Biochemistry and Molecular Biology 138 132-142. (https://doi.org/10.1016/j.jsbmb.2013.04.010)

Tamae D, Byrns M, Marck B, Mostaghel EA, Nelson PS, Lange P, Lin D, Taplin ME, Balk S, Ellis W, et al. 2013 Development, validation and application of a stable isotope dilution liquid chromatography electrospray ionization/selected reaction monitoring/mass spectrometry (SID-LC/ESI/SRM/MS) method for quantification of keto-androgens in human serum. Journal of Steroid Biochemistry and Molecular Biology 138 281-289. (https://doi.org/10.1016/j. jsbmb.2013.06.014)

Tamae D, Mostaghel E, Montgomery B, Nelson PS, Balk SP, Kantoff PW, Taplin ME \& Penning TM 2015 The DHEA-sulfate depot following P450c17 inhibition supports the case for AKR1C3 inhibition in high risk localized and advanced castration resistant prostate cancer. Chemico-Biological Interactions 234 332-338. (https://doi. org/10.1016/j.cbi.2014.12.012)

Taplin ME, Montgomery B, Logothetis CJ, Bubley GJ, Richie JP, Dalkin BL, Sanda MG, Davis JW, Loda M, True LD, et al. 2014 Intense androgen-deprivation therapy with abiraterone acetate plus leuprolide acetate in patients with localized high-risk prostate cancer: results of a randomized phase II neoadjuvant study. Journal of Clinical Oncology 32 3705-3715. (https://doi.org/10.1200/ JCO.2013.53.4578)

Tran C, Ouk S, Clegg NJ, Chen Y, Watson PA, Arora V, Wongvipat J, Smith-Jones PM, Yoo D, Kwon A, et al. 2009 Development of a second-generation antiandrogen for treatment of advanced prostate cancer. Science 324 787-790. (https://doi.org/10.1126/ science.1168175)

Turcu AF, Nanba AT, Chomic R, Upadhyay SK, Giordano TJ, Shields JJ, Merke DP, Rainey WE \& Auchus RJ 2016 Adrenal-derived 11-oxygenated 19-carbon steroids are the dominant androgens in classic 21-hydroxylase deficiency. European Journal of Endocrinology 174 601-609. (https://doi.org/10.1530/EJE-15-1181)

Uemura M, Honma S, Chung S, Takata R, Furihata M, Nishimura K, Nonomura N, Nasu Y, Miki T, Shuin T, et al. 2010 5alphaDH-DOC (5alpha-dihydro-deoxycorticosterone) activates androgen receptor in castration-resistant prostate cancer. Cancer Science 101 1897-1904. (https://doi.org/10.1111/j.1349-7006.2010.01620.x)

van Bokhoven A, Varella-Garcia M, Korch C, Johannes WU, Smith EE, Miller HL, Nordeen SK, Miller GJ \& Lucia MS 2003 Molecular characterization of human prostate carcinoma cell lines. Prostate $\mathbf{5 7}$ 205-225. (https://doi.org/10.1002/pros.10290)

van Rooyen D, Gent R, Barnard L \& Swart AC 2018 The in vitro metabolism of $11 \beta$-hydroxyprogesterone and 11-ketoprogesterone to 11-ketodihydrotestosterone in the backdoor pathway. Journal of Steroid Biochemistry and Molecular Biology 178 203-212. (https://doi. $\operatorname{org} / 10.1016 / j . j s b m b .2017 .12 .014)$

Vandenput L, Labrie F, Mellström D, Swanson C, Knutsson T, Peeker R, Ljunggren O, Orwoll E, Eriksson AL, Damber JE, et al. 2007 Serum levels of specific glucuronidated androgen metabolites predict BMD and prostate volume in elderly men. Journal of Bone and Mineral Research 22 220-227. (https://doi.org/10.1359/jbmr.061018)

Wierman ME, Auchus RJ, Haisenleder DJ, Hall JE, Handelsman D, Hankinson S, Rosner W, Singh RJ, Sluss PM \& Stanczyk FZ 2014 Editorial: the new instructions to authors for the reporting of steroid hormone measurements. Endocrinology 155 4603. (https://doi. org/10.1210/en.2014-1735)

Wu X, Lukacik P, Kavanagh KL \& Oppermann U 2007 SDR-type human hydroxysteroid dehydrogenases involved in steroid hormone activation. Molecular and Cellular Endocrinology 265-266 71-76. (https://doi.org/10.1016/j.mce.2006.12.006)

Wudy SA, Schuler G, Sánchez-Guijo A \& Hartmann MF 2018 The art of measuring steroids: principles and practice of current hormonal steroid analysis. Journal of Steroid Biochemistry and Molecular Biology 179 88-103. (https://doi.org/10.1016/j. jsbmb.2017.09.003)

Yepuru M, Wu Z, Kulkarni A, Yin F, Barrett CM, Kim J, Steiner MS, Miller DD, Dalton JT \& Narayanan R 2013 Steroidogenic enzyme AKR1C3 is a novel androgen receptor-selective coactivator that promotes prostate cancer growth. Clinical Cancer Research 19 5613-5625. (https://doi.org/10.1158/1078-0432.CCR-13-1151)

Zahid H, Simpson ER \& Brown KA 2016 Inflammation, dysregulated metabolism and aromatase in obesity and breast cancer. Current Opinion in Pharmacology 31 90-96. (https://doi.org/10.1016/j. coph.2016.11.003)

Zang T, Tamae D, Mesaros C, Wang Q, Huang M, Blair IA \& Penning TM 2017 Simultaneous quantitation of nine hydroxy-androgens and their conjugates in human serum by stable isotope dilution liquid chromatography electrospray ionization tandem mass spectrometry. Journal of Steroid Biochemistry and Molecular Biology 165 342-355. (https://doi.org/10.1016/j.jsbmb.2016.08.001)

Zhang A, Zhang J, Plymate S \& Mostaghel EA 2016 Classical and nonclassical roles for pre-receptor control of DHT metabolism in prostate cancer progression. Hormones and Cancer 7 104-113. (https://doi. org/10.1007/s12672-016-0250-9)

Received in final form 28 January 2019

Accepted 4 February 2019 https://jme.bioscientifica.com

https://doi.org/10.1530/JME-18-0150 (c) 2019 Society for Endocrinology Published by Bioscientifica Ltd. Printed in Great Britain 